\title{
Physico chemical analysis of puranaghrita (one year old ghee)
}

\author{
Aswathy Kavirajan*1 Suhas Kumar Shetty ${ }^{2}$ and Savitha HP $^{3}$ \\ ${ }^{1}$ PG scholar, SDM College of Ayurveda, Hassan, Karnataka, India \\ ${ }^{2}$ Head and Professor, SDM College of Ayurveda, Hassan, Karnataka, India \\ ${ }^{3}$ Associate Professor, SDM College of Ayurveda, Hassan, Karnataka, India \\ *Email:aswathy.kavirajan@gmail.com
}

\begin{abstract}
Ghrita (clarified butter) which is one year old is mentioned as beneficial for many diseases in Ayurveda classics. It is mentioned as a diet and medicine. Freshly prepared ghrita was stored in anaerobic condition for one year. This was taken and sent for physico chemical analysis to study the various changes that occurred on storage. The results showed the higher level of unsaturation in the old ghrita. Also the lengths of fatty acid chains were found to be shorter which implicated towards its higher utility in brain related disorders. This paper highlights the different physical and chemical parameters of one year old ghee in order to substantiate its therapeutic utility in different ways.

Keywords: Ghrita, physico chemical analysis, Ayurveda, puranaghrita
\end{abstract}

Paper Cited: Kavirajan, A., Shetty, S.K. and Savitha, H.P. (2017). Physico chemical analysis of puranaghrita (one year old ghee). South Asian Journal of Food Technology and Environment, 3(2): 568575.

\section{Introduction}

Clarified butter is called as ghee or ghrita. The word is derived from the root ' $\mathrm{ghr}$ ' which means bright or to make bright. When sprinkled on fire, butterfat enhanced its brightness merged with cause. Butter fat was later christened ghrita, which evolved into ghee (Dhurvey et al., 2012). Ghee is important part of human diet. It is a rich source of dietary energy and contains high calorific value. Ghee contains certain acids which are very important and essential for the human beings. They are vehicle for the fat soluble vitamins. Ghee is complex lipids of glycerides, free fatty acids, phospholipids, sterols, sterol esters, fat soluble vitamins, carbonyls, hydrocarbons and carotenoids (cow ghee). Ghee is usually prepared by four methods: Desi Method, Creamy Butter method, Direct Cream Method and Pre-satisfaction Method. The desi method is most commonly used of the four methods for the preparation (Kumar et al., 2010). The quality of ghee prepared by any of this method depends upon the quality of milk, cream, dahi (Curd), butter, method of preparation, temperature, conditions of storage and type of animal feed. These factors in turn will help in determining physicochemical properties of ghee. The quality of ghee is determined by three parameters: Peroxide value, Flavour and Acidity. The quality of ghee on storage has been measured by acid and peroxide value.

Ghrita is considered as the best among fats (Vaidya, 1995). Ayurveda emphasizes the use of ghrita on daily basis as it has benefits on all systems of the body (Sreekantamoorthy, 2010). It is considered both as a diet and a drug. Ghrita alleviates vata and pitta without increasing kapha much. It enhances digestive fire, memory, intelligence, eyesight and vitalizes the body. Traditionally prepared cows ghrita has higher levels of docosahexaeonic acid (Joshi, 2014). The reference of PurānaGhrita (old ghee) is available along with Ghritain Samhitas (Sreekantamoorthy, 2004). The Ghrita which is stored from one year up to more than one hundred year has enhanced qualities and is known as Purana ghrita, Prapurana Ghrita, Kumbha Sarpi (Sharma, 2007) and Maha Ghrita. It's explanations in Unmada Chikitsa 
could be because of its utmost efficacy in treating psychiatric disorders. It is one among the Dravya which is more potent during Purana Avastha (Sreekandamoorthy, 2007). A noticeable change occurs in the ghrita with passage of time. Freshly prepared ghrita has qualities like softness, unctuousness, pleasant odour whereas purana ghrita is potent, with a penetrating odour. Considering the therapeutic utility of purana ghrita, a thought was given to standardize purana ghrita (one year old). Physico -chemical analysis of one year old ghrita was done to find out the changes occurred after one year of anaerobic storage.

\section{Materials and methods}

Freshly prepared butter was obtained from Nehru butter store in February 2016. Ghrita was prepared as per the ghritakalpana (classical procedure of preparation). It was assessed for ghrita paaka lakshana. This was further allowed to cool to room temperature. It was then stored in an air tight glass container and kept for one year away from light and temperature variations. This was opened after 365 days of incubation. The sample was sent to SDM centre for research in Ayurveda and Allied sciences, Kuthpady, Uduppi, Karnataka, India as per standard procedure (Stahl, 1969; Sethi, 1996; Khandewal, 2006). Following techniques and methods were used for the study.

Analytical Study: The present study, analytical evaluation of Purana Ghrita was carried out to determine the physico-chemical parameters. The study was carried out at S.D.M. Centre for Research in Ayurveda and Allied Sciences, Udupi. Purana Ghrita was analyzed for following parameters as per the references available in protocol for testing published by CCRAS.

- Physical parameters -Refractive index, specific gravity, viscosity.

- Chemical parameters- Acid value, Iodine value, Saponification value, Unsaponifiable matter, Peroxide value.

- Organoleptic characters-colour, touch, odour, taste using sensory organs.

- HPTLC analysis using- Toluene: Ethyl Acetate (9:1) as Solvent system

\section{Physical parameters}

The details of how each physical and chemical parameter which were calculated are illustrated below.

Refractive index: A drop of water was placed on the prism and the drive knob was adjusted in such a way that the boundary line intersects the separatrix exactly at centre. The reading was noted. Distilled water has a refractive index of 1.3325 at $25^{\circ}$ C.Refractive index of ghrita was determined using 1 drop of the sample. The correction was applied to the measured reading to get accurate refractive index. Refractive index of the test samples were measured at $28^{\circ} \mathrm{C}$.

Specific gravity: A specific gravity bottle was cleaned by shaking with acetone and then with ether. The bottle was dried and weight was noted. It was cooled to room temperature and was filled with the test liquid. The weight was noted. The same procedure was repeated using distilled water in place of sample solution.

Viscosity: The given sample was filled in a $U$ tube viscometer in accordance with the expected viscosity of the liquid so that the fluid level stood within $0.2 \mathrm{~mm}$ of the filling mark of the viscometer when the capillary was vertical and the specified temperature was attained by the test liquid. The liquid was sucked or blown to the specified height of the viscometer and the time taken for the sample to pass the two marks was measured. Viscosity was measured using the formula

$$
\frac{\eta_{1}}{\eta_{2}}=\frac{\rho_{1} t_{1}}{\rho_{2} t_{2}}
$$

Where, $\eta_{1-V}$ Viscosity of sample, $\eta_{2}$ - Viscosity of water $t_{1 \text { and }} t_{2}$-Time taken for the sample and water to pass the meniscus

$\rho_{1 \text { and }} \rho_{2}$-Density of sample and water.

\section{Chemical parameters}

Determination of Acid value: $10 \mathrm{~g}$ of the sample was weighed in a conical flask. $50 \mathrm{ml}$ of acid free alcohol-ether mixture $(25+25 \mathrm{ml})$ which was previously neutralized by adding $1 \mathrm{ml}$ of Phenolphthalein solution and titrated against $0.1 \mathrm{~N}$ potassium hydroxide solution was added. When pale pink color persisted for 15 seconds, it 
was considered as the end point. The experiment was repeated twice to get concordant values.

$$
\text { Acid value }=\frac{\text { Volume }(\mathrm{mL}) \text { of } 0.1 \mathrm{~mol} / \mathrm{L} \mathrm{KOH} \text { consumed } \times 5.611}{\text { Weight }(\mathrm{g}) \text { of the sample }}
$$

Determination of Saponification value: About $2 \mathrm{~g}$ of the substance was weighed in a $250 \mathrm{ml}$ round bottom flask. $25 \mathrm{ml}$ of the alcoholic solution of $\mathrm{KOH}$ was added and a reflux condenser was attached. Kept it for boiling on water bath for $1 \mathrm{hr}$, the contents of the flask was rotated frequently. The flask was cooled and $1 \mathrm{ml}$ phenolphthalein solution was added and excess of alkali titrated with $0.5 \mathrm{~N} \mathrm{HCl}$. The number of $\mathrm{ml}$ (a) required was noted. The experiment was repeated with the same quantities of reagents in the same manner omitting the substance. The number of $\mathrm{ml}$ required (b) was noted. The experiment was repeated twice to get concordant values.

$$
\frac{56.1 \times(b-a) \times \text { Strength of } \mathrm{HCl}}{\text { weight of sample taken }}
$$

Determination of Unsaponifiable matter: $5 \mathrm{~g}$ of the substance was weighed into a flask. $50 \mathrm{ml}$ alcoholic $\mathrm{KOH}$ was added into the sample. The mixture was boiled gently but steadily under reflux condenser for one hour. The condenser was washed with $10 \mathrm{ml}$ of ethyl alcohol and the mixture was collected and transferred to a separating funnel. The transfer was completed by washing the sample with ethyl alcohol and cold water. Altogether, $50 \mathrm{ml}$ of water was added to the separating funnel followed by an addition of $50 \mathrm{ml}$ petroleum ether. A stopper was inserted and shaken vigorously for 1 minute and allowed it to settle until both the layers were clear. The lower layer containing the soap solution was transferred to another separating funnel and repeated the ether extraction six times more using $50 \mathrm{ml}$ of petroleum ether for each extraction. All the extracts were collected in a separating funnel. The combined extracts were washed in the funnel 3 times with $25 \mathrm{ml}$ of aqueous alcohol and shaked vigorously. And drawing off the alcohol-water layer after each washing. The ether layer was again washed repeatedly with $25 \mathrm{ml}$ of water until the water no longer turns pink on addition of a few drops of
Phenolphthalein indicator solution. The ether layer was transferred to a tarred flask containing few pieces of pumice stone and evaporated to dryness on a water bath. The flask was placed in an air oven at $85^{\circ}$ cfor about 1 hour to remove the last traces of ether. A few $\mathrm{ml}$ of Acetone was added and evaporated to dryness on a water bath. It was cooled in a desiccator to remove last traces of moisture and then weighed.

Iodine value: $100 \mathrm{mg}$ of sample was accurately weighed in a dry iodine flask. It was dissolved with $10 \mathrm{ml}$ of $\mathrm{CCl}_{4}, 20 \mathrm{ml}$ of iodine monochloride solution was added. Stopper was inserted, which was previously moistened with solution of potassium iodide and flask was kept in a dark place at a temperature of about $17^{0} \mathrm{C}$ for $30 \mathrm{~min}$. $15 \mathrm{ml}$ of potassium iodide and $100 \mathrm{ml}$ of water was added and shaken well. This was titrated with $0.1 \mathrm{~N}$ Sodium thiosulphate, starch was used as indicator. The number of $\mathrm{ml}$ of $0.1 \mathrm{~N}$ sodium thiosulphate required (a) was noted. The experiment was repeated with the same quantities of reagents in the same manner omitting the substance. The number of $\mathrm{ml}$ of $0.1 \mathrm{~N}$ sodium thiosulphate required (b) was noted. The experiment was repeated twice to get concordant values.

$$
\text { Iodine value }=\frac{(b-a) \times 0.01269 \times 100}{\text { weight of sample }}
$$

Peroxide value: $5 \mathrm{~g}$ of the ghrita was weighed accurately into a conical flask, $30 \mathrm{ml}$ of mixture of 3 volumes of glacial acetic acid and 2 volumes of chloroform, added $0.5 \mathrm{ml}$ of potassium iodide was added, allowed to stand for 1 minute, $30 \mathrm{ml}$ of water titrate was added gradually with vigorous shaking with $0.1 \mathrm{M}$ sodium thiosulphate until the yellow color disappeared. $0.5 \mathrm{ml}$ of starch indicator was added and the titration was continued until blue color disappeared.

$$
\text { Peroxide value }=\frac{10(\mathrm{a}-\mathrm{b})}{\text { weight of sample }}
$$

The given sample showed peroxide value of 0.20 . 


\section{HPTLC analysis}

Sample preparation for HPTLC: Sample obtained in the procedure for the determination of unsaponifiable matter was dissolved in $10 \mathrm{ml}$ of chloroform. This was followed for all the sample of Ghee, and chloroform soluble portion was used for HPTLC.

HPTLC: $4,8,12 \mu 1$ of sample was applied on a pre-coated silica gel F254 on aluminum plates to a band width of $8 \mathrm{~mm}$ using Linomat 5 TLC applicator. The plate was developed in Toluene - Ethyl acetate (9:1) and the developed plates were visualized under UV 254 and $366 \mathrm{~nm}$, and after derivatisation in vanillin-sulphuric acid spray reagent and scanned under UV 254nm,
$366 \mathrm{~nm}$ and $620 \mathrm{~nm}$. Rf, colour of the spots and densitometric scan were recorded.

\section{Results and Discussion}

Physico-chemical parameters of Purana Ghee: Although purana ghrita has been emphasized in classics, the physical and chemical properties by virtue of which its therapeutic value has increased remains unexplored (Table 1). A thorough evaluation of its physical and chemical values gives a clear scientific base as how purana ghrita has influence on the brain.

Table 1: Results of Physico-chemical parameters of Purana Ghee

\begin{tabular}{|l|l|}
\hline Parameters & Results $\mathbf{n = 3} \% \mathbf{\% w} / \boldsymbol{w}$ \\
\hline Physical & \\
\hline Refractive index & 1.45732 \\
\hline Specific gravity & 0.9336 \\
\hline Viscosity & 33.893 \\
\hline Chemical & \\
\hline Acid value & 0.38 \\
\hline Saponification value & 220.54 \\
\hline Iodine value & 40.76 \\
\hline Unsaponifiable matter (\%) & 1.84 \\
\hline Peroxide value & 0.20 \\
\hline
\end{tabular}

Table 2: Organoleptic results of Ghee

\begin{tabular}{|l|l|}
\hline Colour & White \\
\hline Touch & Unctuous \\
\hline Odour & Unpleasant \\
\hline Taste & Unpleasant \\
\hline
\end{tabular}

On analyzing the results of chemical parameters, there was an increase in the iodine value and saponification value of the sample. Also the refractive index helped in proving the purity of the compound.

Refractive index is used to measure total solids in milk and condensed milk, purity of ghee, adulteration of milk and water. The given sample showed a refractive index of 1.45 which corresponded to the standard levels of refractive index of ghee. Thus the ghrita which was preserved for one year is free of adulteration and is pure.

The iodine value or number is the number of grams of iodine consumed by $100 \mathrm{~g}$ of fat. A higher iodine value indicates a higher degree of unsaturation. Also higher the iodine value, higher is the reactivity of the compound. It is established earlier that traditionally prepared ghee has more content of DHA. Unsaturated fatty acids have the capability to transcend the blood brain barrier due to its lipophilic nature. Thus one year old ghee has a greater level of unsaturation which emphasizes its usage in brain related disorders.

Saponification value represents the number of milligrams of potassium hydroxide required to saponify one gram of fat under specific conditions. The long chain fatty acids present in fats have low saponification value as 
there are very less carboxylic functional groups per unit mass of fat when compared to short chain fatty acids. The high saponification value clearly states the presence of short chain fatty acids in the sample. Shorter the fatty acid chain, easier it is to get absorbed to brain. Thus the saponification value also hints towards the practical utility of purana ghrita in disorders related to brain.

Organoleptic characters: The organoleptic characters of Purana Ghrita were determined using sensory organs. The organoleptic characters showed changes in color and odour. Color of ghrita mainly depends upon the carotenoids present in it. The present sample is white in colour. Apart from carotenoids, colour is influenced by the type of feed that the cow takes, the climatic conditions of the rearing area etc. Classics state that ghrita when becomes old, its color changes to lighter color. The smell is also found to be unpleasant which was close to smell of rancidity. Classics mention that purana ghrita has a penetrating odour. The results are as follows

Ayurveda emphasizes the usage of ghrita at various places as a treatment modality. It is widely used in panchakarma(the five purificatory procedures) procedures mainly nasya ( nasal medication) and basti ( enema). Nasal mucosa is lipophilic in nature which enables the easy transportation of ghrita towards brain. Blood brain barrier (BBB) also has a lipophilic molecular structure. This makes the lipids and lipid soluble drugs pass easily through
BBB. So the drugs which are given in the form of ghee which are lipids rapidly absorbed in the target areas of central nervous system (Bloch and Qaweasami, 2011) ${ }^{12}$. The rectal epithelium is also lipophilic in nature. Basti is one major treatment modality which uses ghrita as medicine. Form the upper part of rectum, medicine is drained into portal circulation. From the lower part of rectum, it is drained into the vena cava which directly enters into circulation within five to ten minutes of administration.

Ghee is known to have antioxidant property which acts upon the degenerative brain cells and repair them (Athavale et al., 2012). It also acts in normalizing the chemical changes in brain by balancing the neurotransmitters. By applying the theory of similarity, it can be said Mastishka (brain) which resembles molten ghee can be supplemented with clarified butter in various therapies (Sharma and Das, 2009; Monier Williams, 2011; Yadavji, 2011; Yadavji, 2001).

\section{HPLC Analysis}

HPTLC fingerprint of butanol soluble portion of Purana Ghrita has been developed. The purity of the band in the sample extracts was confirmed by comparing the absorption spectra recorded at start, middle, and end positions of the band. The video densitometric images of chromatoplate are depicted. HPTLC densitometric scan at UV 254, $366,620 \mathrm{~nm}$ are presented in Fig. $1 \& 2$. The Rf values are given in Table 3.

\section{Fig. 1: HPTLC photo documentation of chloroform extract of Puranaghritha}

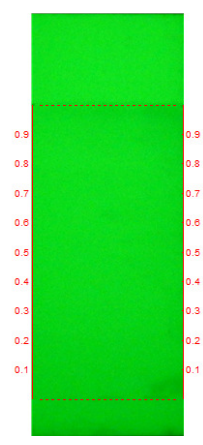

Short UV

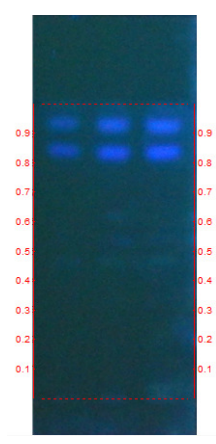

Long UV

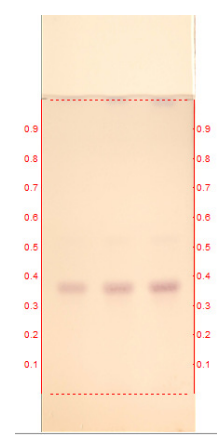

After Derivatisation 
Track 1-Puranaghritha $-4 \mu 1$

Track 2-Puranaghritha $-8 \mu 1$

Track 3-Puranaghritha $-12 \mu 1$

Solvent system - Toluene: Ethyl Acetate (9.0: 1.0)

Table 3: $\mathbf{R}_{\mathbf{f}}$ values of samples

\begin{tabular}{|l|l|l|}
\hline At 254nm & At 366nm & After derivatisation \\
\hline- & - & 0.36 (D. purple) \\
\hline- & 0.47 ( FL. blue) & - \\
\hline- & - & 0.52 (L. purple) \\
\hline- & 0.55 ( FL. blue) & - \\
\hline- & 0.63 ( FL. blue) & - \\
\hline- & 0.84 ( FL. blue) & - \\
\hline- & 0.94 ( FL. blue) & - \\
\hline
\end{tabular}

*F - Fluorescent; L -Light; D - Dark

Fig. 2: Densitometric scan of Puranaghritha

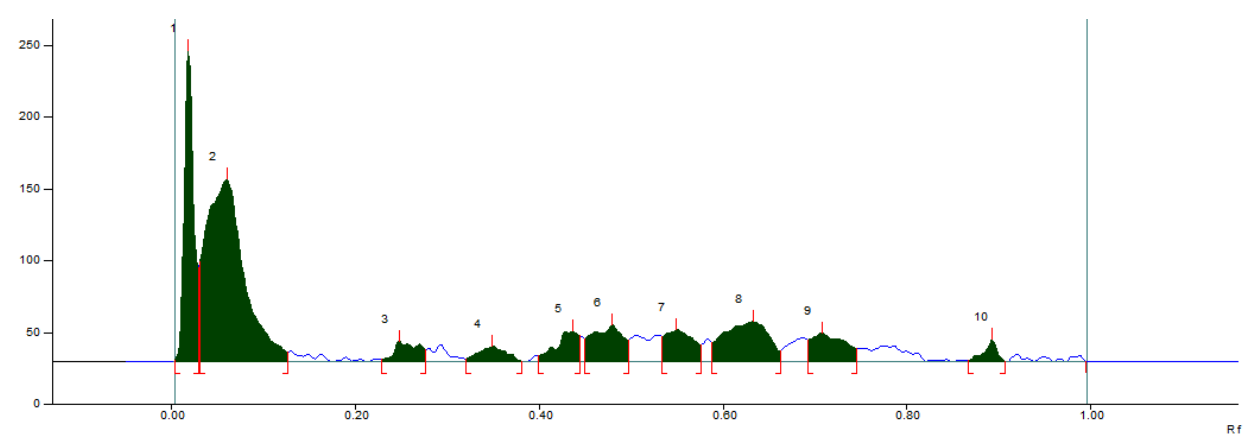

\begin{tabular}{|c|c|c|c|c|c|c|c|c|c|}
\hline Peak & $\begin{array}{c}\text { Start } \\
\text { Position }\end{array}$ & $\begin{array}{l}\text { Start } \\
\text { Height }\end{array}$ & $\begin{array}{c}\text { Max } \\
\text { Position }\end{array}$ & $\begin{array}{l}\text { Max } \\
\text { Height }\end{array}$ & $\underset{\%}{\operatorname{Max}}$ & $\begin{array}{c}\text { End } \\
\text { Position }\end{array}$ & $\begin{array}{l}\text { End } \\
\text { Height }\end{array}$ & Area & $\begin{array}{c}\text { Area } \\
\%\end{array}$ \\
\hline 1 & $0.00 \mathrm{Rf}$ & 1.1 $\mathrm{AU}$ & $0.02 \mathrm{Rf}$ & $216.8 \mathrm{AU}$ & $43.32 \%$ & $0.03 \mathrm{Rf}$ & $65.6 \mathrm{AU}$ & $1593.0 \mathrm{AU}$ & $17.73 \%$ \\
\hline 2 & $0.03 \mathrm{Rf}$ & $69.8 \mathrm{AU}$ & $0.06 \mathrm{Rf}$ & $127.0 \mathrm{AU}$ & $25.36 \%$ & $0.13 \mathrm{Rf}$ & $6.6 \mathrm{AU}$ & $3757.7 \mathrm{AU}$ & $41.81 \%$ \\
\hline 3 & $0.23 \mathrm{Rf}$ & $1.4 \mathrm{AU}$ & $0.25 \mathrm{Rf}$ & $14.4 \mathrm{AU}$ & $2.88 \%$ & $0.28 \mathrm{Rf}$ & $8.4 \mathrm{AU}$ & 266.4 AU & $2.96 \%$ \\
\hline 4 & $0.32 \mathrm{Rf}$ & $2.0 \mathrm{AU}$ & $0.35 \mathrm{Rf}$ & $10.5 \mathrm{AU}$ & $2.09 \%$ & $0.38 \mathrm{Rf}$ & $0.4 \mathrm{AU}$ & $230.4 \mathrm{AU}$ & $2.56 \%$ \\
\hline 5 & $0.40 \mathrm{Rf}$ & $4.0 \mathrm{AU}$ & $0.44 \mathrm{Rf}$ & $21.3 \mathrm{AU}$ & $4.25 \%$ & $0.45 \mathrm{Rf}$ & $18.3 \mathrm{AU}$ & 378.5 AU & $4.21 \%$ \\
\hline 6 & $0.45 \mathrm{Rf}$ & $15.7 \mathrm{AU}$ & $0.48 \mathrm{Rf}$ & $25.3 \mathrm{AU}$ & $5.06 \%$ & $0.50 \mathrm{Rf}$ & $14.8 \mathrm{AU}$ & $611.7 \mathrm{AU}$ & $6.81 \%$ \\
\hline 7 & $0.53 \mathrm{Rf}$ & $17.4 \mathrm{AU}$ & $0.55 \mathrm{Rf}$ & $22.0 \mathrm{AU}$ & $4.40 \%$ & $0.58 \mathrm{Rf}$ & $11.7 \mathrm{AU}$ & $504.0 \mathrm{AU}$ & $5.61 \%$ \\
\hline 8 & $0.59 \mathrm{Rf}$ & $13.3 \mathrm{AU}$ & $0.63 \mathrm{Rf}$ & $27.8 \mathrm{AU}$ & $5.55 \%$ & $0.66 \mathrm{Rf}$ & $7.5 \mathrm{AU}$ & $976.6 \mathrm{AU}$ & $10.87 \%$ \\
\hline 9 & $0.69 \mathrm{Rf}$ & $15.2 \mathrm{AU}$ & $0.71 \mathrm{Rf}$ & $20.2 \mathrm{AU}$ & $4.03 \%$ & $0.75 \mathrm{Rf}$ & $8.8 \mathrm{AU}$ & $519.4 \mathrm{AU}$ & $5.78 \%$ \\
\hline 10 & $0.87 \mathrm{Rf}$ & $1.0 \mathrm{AU}$ & $0.89 \mathrm{Rf}$ & $15.3 \mathrm{AU}$ & $3.07 \%$ & $0.91 \mathrm{Rf}$ & $0.4 \mathrm{AU}$ & 149.7 AU & $1.67 \%$ \\
\hline
\end{tabular}

Fig 2a. At 254nm 
Physico chemical analysis of puranaghrita (one year old ghee)

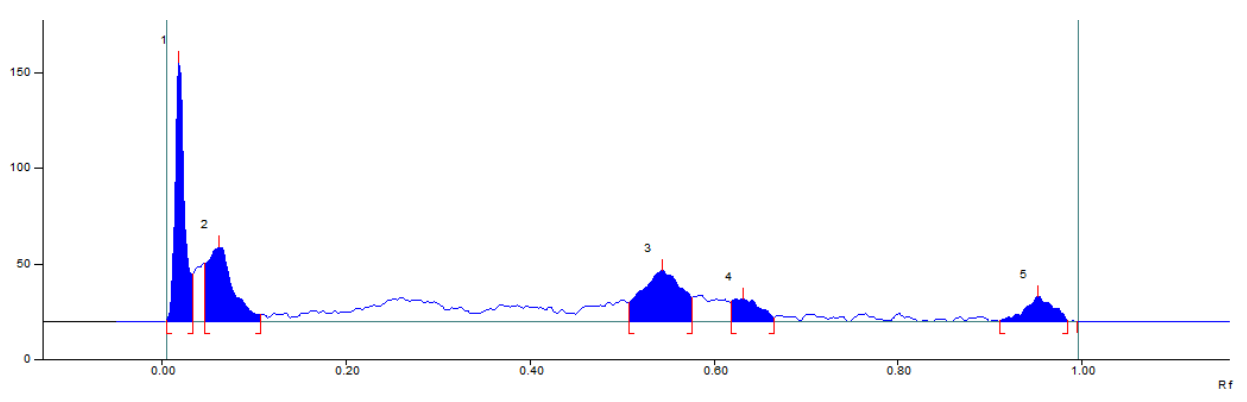

Track 3, ID: Purana ghritha

\begin{tabular}{|c|c|c|c|c|c|c|c|c|c|}
\hline Peak & $\begin{array}{c}\text { Start } \\
\text { Position }\end{array}$ & $\begin{array}{c}\text { Start } \\
\text { Height }\end{array}$ & $\begin{array}{c}\text { Max } \\
\text { Position }\end{array}$ & $\begin{array}{l}\text { Max } \\
\text { Height }\end{array}$ & $\underset{\%}{\operatorname{Max}}$ & $\begin{array}{c}\text { End } \\
\text { Position }\end{array}$ & $\begin{array}{l}\text { End } \\
\text { Height }\end{array}$ & Area & $\begin{array}{c}\text { Area } \\
\%\end{array}$ \\
\hline 1 & $0.01 \mathrm{Rf}$ & $0.8 \mathrm{AU}$ & $0.02 \mathrm{Rf}$ & $135.4 \mathrm{AU}$ & $59.94 \%$ & $0.03 \mathrm{Rf}$ & $25.0 \mathrm{AU}$ & $956.5 \mathrm{AU}$ & $30.65 \%$ \\
\hline 2 & $0.05 \mathrm{Rf}$ & $30.2 \mathrm{AU}$ & $0.06 \mathrm{Rf}$ & $38.9 \mathrm{AU}$ & $17.20 \%$ & $0.11 R f$ & $3.6 \mathrm{AU}$ & $793.0 \mathrm{AU}$ & $25.41 \%$ \\
\hline 3 & $0.51 \mathrm{Rf}$ & $9.6 \mathrm{AU}$ & $0.55 \mathrm{Rf}$ & $26.4 \mathrm{AU}$ & $11.71 \%$ & $0.58 \mathrm{Rf}$ & $12.5 \mathrm{AU}$ & $828.3 \mathrm{AU}$ & $26.54 \%$ \\
\hline 4 & $0.62 R f$ & $10.3 \mathrm{AU}$ & $0.63 \mathrm{Rf}$ & $12.0 \mathrm{AU}$ & $5.32 \%$ & $0.67 \mathrm{Rf}$ & $2.1 \mathrm{AU}$ & $258.8 \mathrm{AU}$ & $8.29 \%$ \\
\hline 5 & $0.91 \mathrm{Rf}$ & $0.5 \mathrm{AU}$ & $0.95 \mathrm{Rf}$ & $13.2 \mathrm{AU}$ & $5.84 \%$ & $0.99 \mathrm{Rf}$ & $0.6 \mathrm{AU}$ & $284.4 \mathrm{AU}$ & $9.11 \%$ \\
\hline
\end{tabular}

Fig 2b: At 366nm

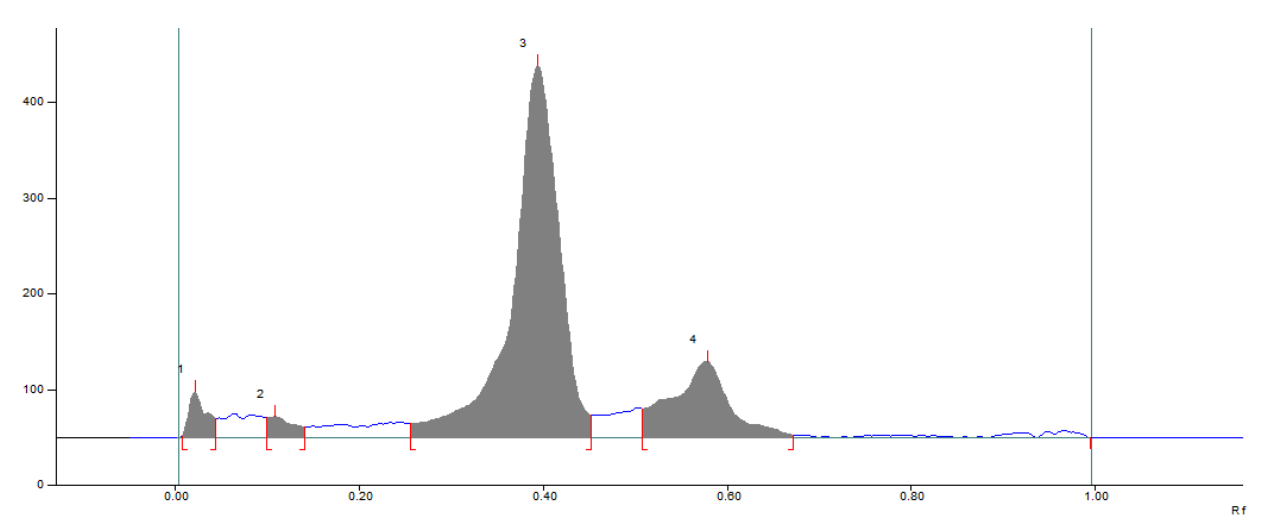

Track 3, ID: Purana ghritha
\begin{tabular}{|r|r|r|c|c|c|c|c|c|c|}
\hline Peak & $\begin{array}{c}\text { Start } \\
\text { Position }\end{array}$ & $\begin{array}{c}\text { Start } \\
\text { Height }\end{array}$ & $\begin{array}{c}\text { Max } \\
\text { Position }\end{array}$ & $\begin{array}{c}\text { Max } \\
\text { Height }\end{array}$ & $\begin{array}{c}\text { Max } \\
\%\end{array}$ & $\begin{array}{c}\text { End } \\
\text { Position }\end{array}$ & $\begin{array}{c}\text { End } \\
\text { Height }\end{array}$ & Area & $\begin{array}{c}\text { Area } \\
\%\end{array}$ \\
\hline $\mathbf{1}$ & $0.01 \mathrm{Rf}$ & $1.1 \mathrm{AU}$ & $0.02 \mathrm{Rf}$ & $48.3 \mathrm{AU}$ & $8.98 \%$ & $0.05 \mathrm{Rf}$ & $20.1 \mathrm{AU}$ & $653.4 \mathrm{AU}$ & $3.48 \%$ \\
\hline $\mathbf{2}$ & $0.10 \mathrm{Rf}$ & $20.5 \mathrm{AU}$ & $0.11 \mathrm{Rf}$ & $21.8 \mathrm{AU}$ & $4.06 \%$ & $0.14 \mathrm{Rf}$ & $11.1 \mathrm{AU}$ & $452.8 \mathrm{AU}$ & $2.41 \%$ \\
\hline $\mathbf{3}$ & $0.26 \mathrm{Rf}$ & $14.4 \mathrm{AU}$ & $0.40 \mathrm{Rf}$ & $387.7 \mathrm{AU}$ & $72.12 \%$ & $0.45 \mathrm{Rf}$ & $23.4 \mathrm{AU}$ & $14083.0 \mathrm{AU}$ & $75.04 \%$ \\
\hline $\mathbf{4}$ & $0.51 \mathrm{Rf}$ & $30.2 \mathrm{AU}$ & $0.58 \mathrm{Rf}$ & $79.8 \mathrm{AU}$ & $14.85 \%$ & $0.67 \mathrm{Rf}$ & $2.4 \mathrm{AU}$ & $3579.2 \mathrm{AU}$ & $19.07 \%$ \\
\hline
\end{tabular}

Fig 2C: Scan after derivatisation at $620 \mathrm{~nm}$

\section{Conclusion}

The findings suggest that traditionally prepared and stored ghrita has more levels of unsaturation and has greater capability to transcend the blood brain barrier. This result opens up a scope to use purana ghrita in brain related pathologies.

\section{References}

1. Athavale, A., Jirankalgikar, N., Nariya, P. and Dev, S. (2012). Evaluation of $I n$ Vitro Antioxidant Activity of Panchagavya: A Traditional Ayurvedic Preparation. International Journal of 
Pharmaceutical and Scientific Research. 3(8): 2543-2549

2. Bloch, M.H. and Qaweasami, A. (2011). Omega-3 fatty acid supplementation for the treatment of children with ADHD symptomatology: systemic review and meta-analysis, Journal of American Academy of Child and Adolescent Psychiatry, 50(10): 99-100.

3. Dhurvey, Y.R., Kawtikwar, P.S. and Sakarkar, D.M. (2012). Evaluation of physic-chemical properties of cow ghee before and after hydrogenation. International Journal of ChemTech Research, 4(1): 185-189.

4. http://ccras.nic.in/sites/default/files/viewp df/Ayurveda/8.6\%20\%20Research\%20an d\%20Development.pdf

5. http://ecoursesonline,iasri.in/mod/resourse /view.php?id=5795Lessson37

6. Joshi, K.S. (2014). Docosahexaenoic acid content is significantly higher in ghrita prepared by traditional Ayurvedic method. Journal of Ayurveda Integrated Medicine, 5: 85-88.

7. Kumar, M., Sharma, V., Lal, D., Kumar, A. and Seth, R. (2010). A comparison of the physico-chemical properties of lowcholesterol ghee with standard ghee from cow and buffalo creams. International Journal of Dairy Technology, 63(2): 251255.

8. Sharma, P. and Sharma, G. (2006). Kaiyyadevanighantu Chaukumbha Orientala Varanasi, Ghrtavarga, p. 370372

9. Sharma, R.K and Das, B. (2009). Charaka: CharakaSamhita of Agnivesha, revised by Charaka and Dridhabala with the Ayurveda - Dipika commentary of Chakrapanidatta, Chaukamba Orientalia. SutraSthana, 1/44.

10. Sreekandamoorthy, K.R. (2007). Vagbhata'sAstangaHridaya (English translation ed. 5): 2: 585

11. Sreekantamoorthy, K.R (2004). Astanga Samgraha of Vagbhata (translation English) $8^{\text {th }}$ edition Varanasi: Chaukumbha Orientalia: 1: 16

12. Sreekantamoorthy, K.R. (2010). Sushrutha Samhita (English Translation)

\author{
Reprint,Varanasi: \\ Orientalia: 1: 144 \\ Chaukumbha
}

13. Vaidya B.H.P (1995). Vagbada: Ashtanga Hridaya with the Sarvanga Sundari commentary of Indu. Chaukamba orientalia. Sutra Sthana, 5/37-39

14. Williams, M. Monier. (2011). A English Sanskrit dictionary (Reprint 6th ed.). Motilal Banarasidas Publishers Pvt Ltd. P.61

15. Yadavji, T.A. (2001). Susrutha: Susrutha Samhitha with Nibanda sangraha commentary of Delhana (2nd ed.), Chaukamba Krishnadas academy. Chikitsa Sthana, 3/69.

16. Yadavji, T.A. (2001). Susrutha: Susrutha Samhitha with Nibanda sangraha commentary of Delhana (2nd ed.), Chaukamba Krishnadas academy. Sutra Sthana 27/56.

\begin{tabular}{|ll|}
\hline Received & : August, 2017 \\
Revised & : Sept., 2017 \\
Published & : Dec., 2017 \\
\hline
\end{tabular}

